QK

525

J78X

Bot.

\title{
JONES
}

\section{FERNS OF THE WEST}

\section{SMITHSONIAN}

LIBRARIES 



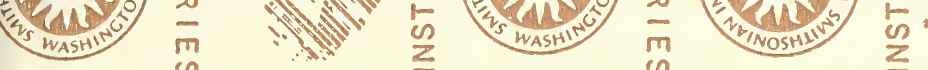

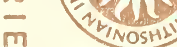

BRARIES SMITHSONIAN INSTITUTION NOILIIISNI NGINOSHLIWS $S \exists I Y \forall \forall$
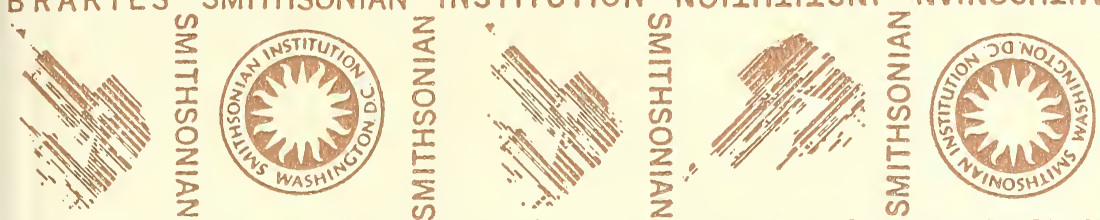

$\frac{n}{3}$
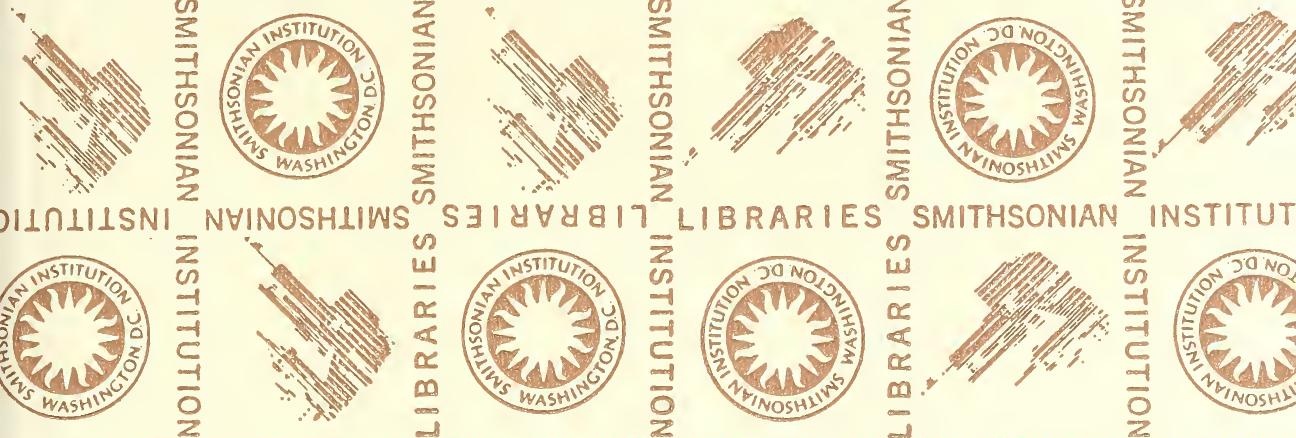

INSTITUT
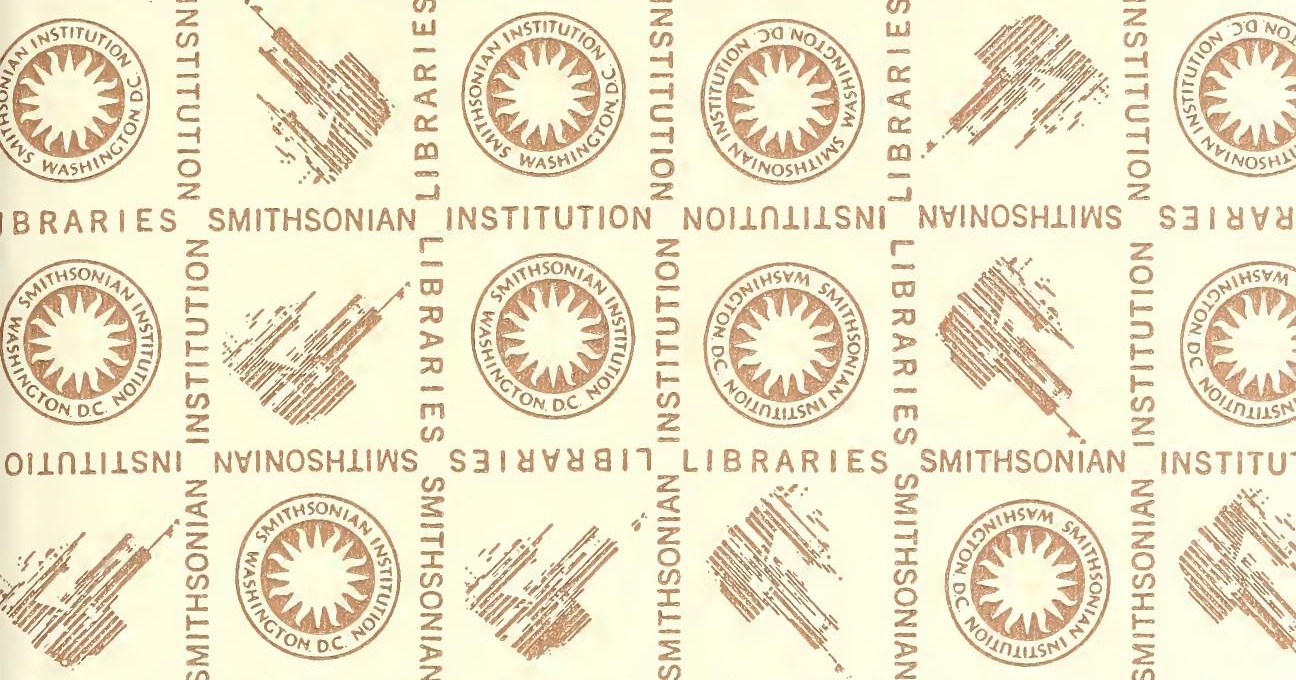

LIBRARIES
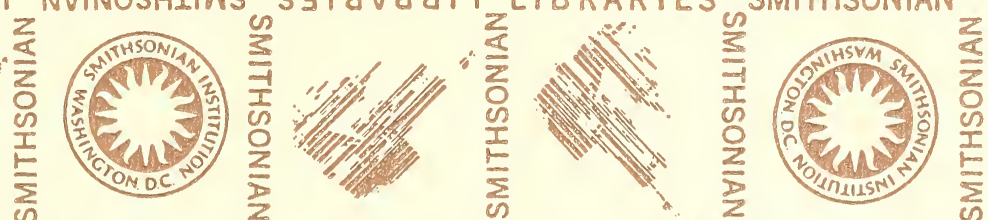

INSTITU
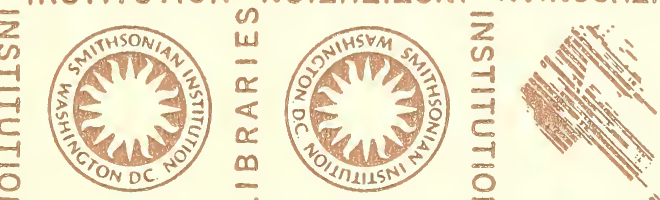

$\frac{w}{\alpha}$

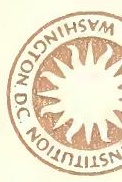

SMITHSONIAN

INSTITU
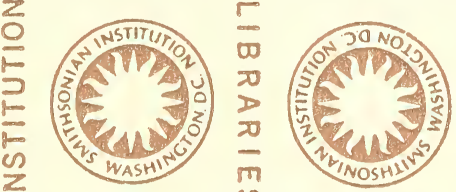

$z$
0
5
5
5
2
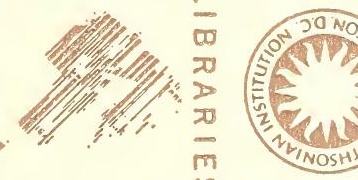

NHINOSHIIWS S
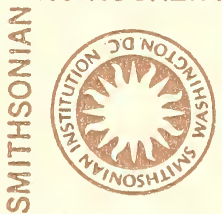

$\frac{0}{3}$

LIBRARIES

SMITHSONIAN
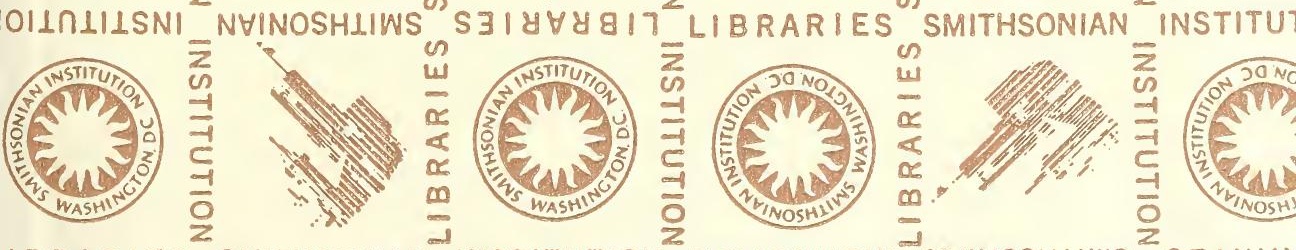





\section{0}
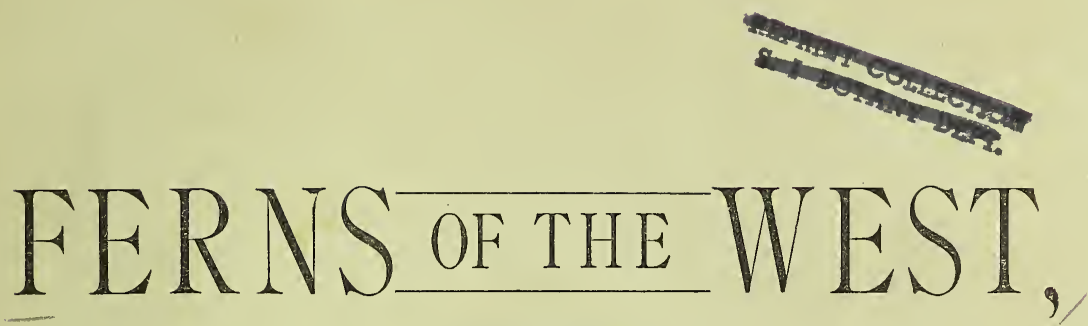

CONTAINING DESCRIPTIONS OF ALL THE FERNS KNOWN TO EXIST IN. THE WEST, FROM NEBRASKA TO THE PACIFIC OCEAN AND FROM MEXICO TO SOUTH AMERICA; ALSO, A FULL ACCOUNT OF THE STRUC-

TURE OF FERNS, THEIR MODE OF GROWTH, HABITS AND DISTRIBUTION.

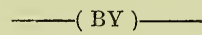 \\ $-(\mathrm{BY})$ \\ aeme \\ MAROUS F. JONHS, A. M. $\rightarrow \infty$}

Published by the Author:

SALT LAKE CITY, UTAH, U. S. A.

I 882 . 


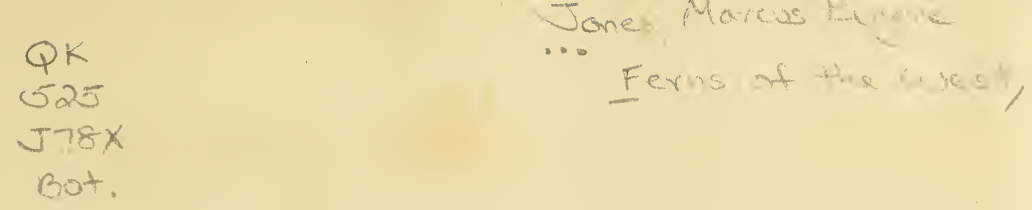

\section{PREFACE.}

The following account of the ferns of the West has been prepared to enable any one, who is not familiar with Botany, to determine the names of all the ferns known to exist in the United States west of Kansas, from Mexico to British America.

Technical terms have been avoided as far as possible, but, for those which are used, a glossary is provided fully explaining them.

An account of the distribution of ferns in general and ours in particular, their habits and morphology will be found, giving such information as will enable anyone to study our ferns intelligently without the use of other works.

That such a work as this is needed, is apparent from the fact that to determine all our ferns, would require Eaton's Ferns of North America, or Bot. Cal. Vol. II, Wheeler's Rep., Gray's Manual, and various copies of Torrey Bulletin, costing not less than $\$ 15$, or $\$ 20$. These works are practically out of the reach of the majority.

Great care has been taken to note in the keys any exceptions that occur, so that the book may be relied upon as scientifically accurate. It is too much to hope that it will never fail to lead to the correct species; for the variations of many species are not accurately known: but it is hoped that it will describe our species, as far as they are known. The writer will esteem it a favor to be apprized, of any inaccuracies in the work.

The plan upon which our plants are here described, is to place the most important characteristics of each species first, and to contrast those of the plants which are most nearly related. The properties which are common to many, but cannot be worked into the keys, and those which sometimes do, and sometimes do not, exist in the same plant, though interesting to a fern-specialist, have no place in a scheme like this, and so are omitted.

If this attempt at arranging in a cheap and careful way the scattered materials on this subject, shall remove the useless difficulties that surround our ferns; shall add to the pleasure of all by providing a satisfactory means of studying them; and shall lead to a more extensive and thorough knowledge of plants in general, the labor of preparing this work will be repaid, and the writer's purpose will be accomplished.

Salt Lake City, Oct. I 7, I88 I.

Marcus E. Jones. 



\section{FERNSOF THE WEST.}

$\S$ I. General. - Ferns have attracted the attention of lovers of nature from time immemorial, since their gracefulness, delicacy, and varied forms place them among the loveliest of plants. The literature of the day is full of allusions to them; several great departments of painting are not complete without them; in our homes they are most eagerly sought to heighten the beauty of drawings and paintings, to ornament the walls, for wreaths, vases and an infinite variety of uses. It is, therefore, not surprising that people turn first to these beautiful plants to learn their names and manner of growth.

Where shall we find them? There is scarcely a place from which they are absent. In the far north and on lofty mountains above the limit of forests, the delicate bladder-fern and the firmer rock-brake and shieldfern peep from the rocks or wave over alpine rivulets. The woods, ravines, and rocky dells of the east are tull of their beautiful forms. From the rocks hang graceful bladder-ferns, blue cliff-brakes, lip-ferns, polypodys, and spleenworts; while along watercourses and shaded ravines are multitudes of maiden-hair, brakes, chain-ferns, spleenworts, walkingleaf, beech-, shield-, ostrich-, sensitive , climbing and flowering ferns. In the Southern States, especially in Florida, are the most beautiful ferns of the United States. But it is in the-tropical countries that they are the most numerous and attain the greatest perfection. There are the moss-like Hymenophyllums and stately tree ferns whose great fronds, often twenty feet long, make a perfect canopy overhead. Between these extremes are myriads of ferns of all degrees of beauty and size.

$\$$ 2. OUR REGION.-Of the three thousand species known, over two- 
thirds inhabit the tropics; nearly two hundred are found in the United States; and about seventy in the far West.

Though the ferns of our region are few, they are sought by botanists and amateurs more than those of any other part of our land, because of their scarcity, their many peculiarities, and the frequent discovery of new species, as well as for their beauty.

In the West the lack of moisture has kept away our eastern ferns, leaving the field open to a few species that are able to resist the drought. These are very woolly, hairy, or powdery. In the higher mountains and along the Pacific coast where there is more moisture, a few eastern ferns grow, together with many others of interest.

$\S$ 3. Habits. - The most favorable localities for the growth of ferns are damp and shady ravines (where all the larger kinds occur); next come the clefts of wet precipitous rocks, especially where they face to the north; here grow the bladder-and rock-ferns, cliff-brakes, the small spleenworts and shield-ferns; beneath loose rocks on the mountains and hills the Woodsias, cliff- and rock-brakes are found ; on the hillsides, growing like other plants, are the gold-fern, brake, large spleenworts, and shield-ferns; around the few springs and watercourses in arid regions the maiden-hair ( $A$. Capillus-Veneris) grows; and in the north on decaying logs, stumps and trees (sometimes two hundred feet above the ground) grow the polypodys.

$\S$ 4. MODE OF GRowTH.-On examining the under side of a ripe fern-leaf there will be found a delicate brown powder which is composed of a multitude of small grains, each of which is able to produce one or more fern plants. These minute seeds do not have little plants already formed in them as true seeds do, and so they have received the name of "spores."

After a spore has lain in a favorable place for a time, it absorbs water, swells, bursts its coat, and spreads out over the ground forming a little green leaf (prothallium) from whose under surface many small hairs grow downwards and become roots. This little leaf is composed of innumerable cells (so small that it requires a high magnifying power to discover them), some of which grow in a peculiar manner. A partition is formed across the middle making two cells, an upper (archegonium) and a lower. The lower cell fills itself with mucilage which afterwards absorbs water till it bursts through the under side of the leaf, leaving a little tube behind which leads to the upper cell. On the margin of our little leaf is a row of still different cells (antheridia), which as they grow project below the leaf like little balls. These are filled with still smaller bodies (antherozoids) floating in them. These are covered with coiled threads, the front ones having little hairs upon them which, when the cells (antheridia) burst, move back and forth continually and drive them through the water (for they do not develop except in water) in one direction. These correspond to the grains of pollen in flowering plants. As they move through the water, some of them enter the tubes and reach and fertilize the cells (archegonia) which immediately begin to grow. As the cell enlarges it protrudes below the leaf, and a part of it (called the "foot") fastens upon the leaf drawing nourishment from the other 
cells. By the additional material thus obtained a little fern is soon formed, with a root stem and leaf of its own. The leaves are very small at first, but each succeeding one is larger, as the root increases, until the plant is fully grown.

When the leaf is ready to produce fruit, in certain definite places (according to the kind of fern) there arise minute projections, half a dozen or more in a cluster, from the lower side of the leaf. These are composed of one cell each. As the cell grows, it divides, the one next the leaf becoming a kind of stalk, while the other divides into five, four of which enclose the fifth. Each of the four divides into an outer and an inner cell; the outer ones form a stout ring, and the inner ones disappear, leaving the fifth cell floating free in the watery fluid which takes their place. This floating cell continues to grow till it breaks up into a number of bead-like bodies or cells which are the spores. The case containing the spores is called the spore-case. As this ripens, the ring of cells shrinks till it cannot endure the strain longer, when it splits crosswise (in our ferns) and scatters the spores. These float out upon the air till they come to rest in some favored spot where they begin anew the great round of life.

\$. Peculiarities. Explanations of Terms Used. - The leaves of ferns are coiled in a ball in the bud, unrolling as they grow, and growing only at the tip. This peculiarity has given them the name of "acrogens" (growing from the top).

As the leaves of ferns are so peculiar, their parts have received special names ; the so-called "stem" is named the "stalk," or "stipe," and the leaf-like part the "frond." A frond is entire when it is not cut, toothed, nor divided in the least. It is toothed when the edge is notched like a saw (it is serrate when the teeth point toward the tip of the frond, toothed when the teeth point straight out, scalloped or crenate when the teeth are rounded). It is cut or incised when the edge is gashed deeply and irregularly. It is lobed when divided about half way to the midrib, (the midrib is the prolongation of the stalk, the term is also applied to the midveins of pinnæ, pinnules and final divisions.) It is paried or pinnatifid when divided almost to the midrib (leaving only a little of the green part of the frond between the parting and the midrib). It is divided when cut clean to the rachis (the midrib in all divided fronds is called the rachis).

Divided fronds are said to be pinnate (because the divisions branch from the rachis like the veins on a feather; Latin pinna, a feather); the divisions are called pinne. If the pinnæ are themselves divided, the frond is said to be bi-pinnate, or iwice pinnate; and the divisions of the pinnæ are called pinnules (little pinnæ). If the pinnules are divided, the frond is tri-pinnate, or thrice pinnate, and so on to quadri-pinnate, etc. Sometimes the frond is so much divided that the final divisions are only one forty-eighth of an inch long; the primary rachis, in that case, branches into secondary, tertiary, etc. rachises.

By holding any delicate fern up to the light the midrib (of the main frond or its divisions) will be seen to branch. These branches are called veins; and their branches veinlets. The midrib, rachis, veirs, 
etc., branch in various ways; sometimes the stalk divides at the top into two or more rachises, as in the maiden-hair; at other times there is a main rachis with alternate (where the branches come out on opposite sides, but one higher up than the other) or opposite branches. Usually the veinlets run side by side to the margin, but sometimes branches go across from one to the other forming a network.

There are various outgrowths from the surfaces of ferns; some of them are of the utmost importance, Occasionally fronds bear little bulbs at the tip, or rarely along the surface; almost all have chaffy scales on the rootstock, stalk and rarely on the frond itself: many are covered with powder, hair or wool: but the most important outgrowths are the spore-cases (sporangia). These are by nature transformed hairs, as the flowers of higher plants are transformed leaves and stems. They spring from the epidermis (skin of the frond), usually that of the under side of the frond. They are flat (except in Aneimia) and coiled into a ring which, at maturity, splits cross-wise and releases the minute spores. The spore-cases usually are clustered, forming little spots or lines which are called fruit dots (sori). These are often covered by a scaly or papery substance called the indusium; often they are collected along the margin of the frond, which is rolled in so as to cover them, forming a false indusium called the involucre. Upon the presence or absence of the indusium and involucre and the arrangement of the fruit-dots, depends the whole classification of our ferns. It is therefore of the first importance that we know just what the indusium, involucre and fruit-dots are, and where they are.

Some fronds of all kinds of ferns do not bear, but there are a few ferns which have two kinds of fronds-those which always bear, and those which never bear; the former are called fertile fronds, and the latter sterile fronds. These two kinds usually differ much in appearance, but they always spring from the same root. In the polypodys the fruitdots are situated at the ends; in others, at the forks; and in others along the back of the veinlets or veins (as in the shield and bladder-ferns and the Woodsias): in a few they are along the sides of the veins (as in spleenworts and chain-ferns). They also occur either in clusters or lines on the ends of the veinlets at the margin of the frond (as in Notholcena, the brake, etc).

§6. How to Analyze.-Having provided ourselves with a pocket microscope (the folding brass "linen provers" are the best, and cost only half a dollar; - the writer is not the agent for them, however!) and having gathered a ripe fern, with the root and sterile fronds, if there are any; we proceed to learn its name.

Since we know that the fruit is a brown powder, we should search out the places from which it comes. If, after blowing off the loose grains, we see that it comes from certain round or roundish spots, which have no covering (indusium), are not on the very margin of the frond, but are on the ends of little veinlets in the frond, it is a polypody. If the fruit-dot is round and covered by an indusium (young fruit-dots should be examined for the indusium, for the riper ones often obscure it by the abundance of powder which they discharge) it belongs to the 
tribe Aspidiea. If there is no apparent indusium (it being minute or on the under side of the fruit-dot), and the fruit-dot is on the back of the vein (so that it conceals the vein), not on the end, it belongs to the same tribe. If the fruit-dots are longer than broad, and are either straight or horse-shoe shaped, are situated on the upper side of the veins (so that the veins are not concealed by them), and are covered by an indusium which is closed on the side next the vein and.open on the other, so forming a little pocket, it is a spleenwort. If the fruit-dots are rather or very long, parallel to the midrib, and provided with an indusium like the spleenworts and situated on the side of the veins, it belongs to the tribe Blechnea. If there appears to be no distinct fruit-dot nor indusium, but the spores are concealed along the incurved edge of the frond (at least when the frond is young), it belongs to the tribe Pteridea. But i, the spores occur along the edge of the frond, and it is not curved over them (at least when young) and there is no indusium, or if the spores arise in narrow lines along the veins and are devoid of an indusium, it belongs to the tribe Grammitidea. If, however, it does not belong to any of these, and if the frond is pinnate and the two lower pinnæe are long stalked and bear all the fruit, the upper part of the frond being sterile, it is an Aneimia. In case this test fails, it must belong to an entirely different order, the fern-like plants, the Ophioglossacea. In these plants the young fronds do not unroll as they grow, the upper and fertile part is very different from the lower and sterile part. In one kind the lower part looks like an oval * and entire leaf (the whole plant resembles an orchid); in the other kind the lower part resembles a fern, but the upper is full of fruit and rolled together.

After analyzing a few ferns, the learner will turn at once to the "key," which follows, and take up tribe I. If his fern is not a polypody (described in tribe I) he will turn to tribe II, and so on from tribe to tribe till he reaches the right one; when this is reached, he will turn to the genera (kinds of fern, such as Notholana, Pteris, Lomaria, etc.) passing from one to the other till the right genus is found. Then he should turn to the page where the genus is described. Let us suppose that it is the genus Cheilanthes (lip-fern) and the species Lindheimeri. After reading the description of the genus, and, being sure of it, the description in Italics following " $*$ " should be read (and that only"; as it does not fit our plant, we skip everything to "**"; this likewise does not agree with the plant in hand, so we turn to " $* * *$ "; this agrees, then we turn to " + " under it; the description here does not fit, so we turn to " $++"$; as this is the right one, we read under " $++"$; this not being right, we read " ++++ "; as this is the right description we are now sure that the plant is C.myriophylla or C. Lindheimeri. We read the description of each and decide that it is Lindheimer's lip-fern. It takes but a few minutes to find the correct name of a fern in this way, and it is a pleasant task; but if there were no key we should be compelled to read every description before deciding what our plant's correct name is.

$\S .7-$ What NeXt? Having found the correct name of our fern, shall

* See Glossary for definition. 
we lay it aside and complacently rest from our labors? If we visit a mining camp for the first time, and learn that there is a smelter near, we would be strange people if we did not go through it, and not rest till we understood the purpose and workings of the complicated machinery in every detail. So with plants; after our introduction to them (for learning a narne is nothing more), we should never cease to study their habits, their modes of growth, and the uses of every organ in root, stem and leaf. Many books have been written on ferns, and many men have spent their lives in research upon them, but the field is hardly opened, much less explored. Since the field is practically inexhaustible, yields such rich returns, and its materials lie at every door, let us look about us with more care, and try to discover and comprehend the subtle forces which are busy day and night rearing up these beautiful plant structures which have been the delight of the world from the earliest ages.

\section{ORDER I.-OPHIOGLOSSACEÆ.}

Fern-like plants. Fronds not rolled up in the young state; fruitbearing portion rising from the sterile part below in spikes or panicles, and composed of very many large round spore-cases, splitting cross-wise, and arising from the tissue of the frond (not the epidermis, as in true ferns). Prothallium developing below the ground.

An order of three genera and twenty species.

\section{Botrychium, Swartz. Grape-Fern, Moonwort.}

Fronds from a bud enclosed in the stalk of the previous season, not net-veined, fern-like below; spore-cases separate, in a double row on the branches of the fertile part. Growing in wet or boggy places.

Ten species, seven North American.

* Sterile portion not long stalked.

- Sterile portion pinnate only.

B. Iunaria L. Sterile portion very short-petioled; near the middle of the stalk (which rises from the ground and bears the fertile part at the top), oblong, having five to fifteen moon-shaped or fan-shaped obtuse divisions; veins forking repeatedly; fertile part, two to three times pinnate. Plant four to ten inches high, fleshy.

Bard Creek, Colorado (Parry). Is found in various parts of the world.

B. Simplex, Hitchcock. Sterile portion, short-petioled, near the base of the stalk, pinnately lobed into three to seven broadly obovate divisions, or undivided and roundish, (but not net-veined, as in Ophioglossum). Fertile portion once or twice pinnate.

Variety compositum, Milde. A low alpine plant, with sterile portion about an inch long, of three entire or cut divisions.

California and Yellowstone Park. The typical form in the eastern States and Europe. Rare.

B. Boreale Milde is credited to Unalaska, but does not reach our limits. 
++ Sterile portion more than once pinnate.

B. lanceolatum, Angstrœm. Sterile portion sessile near the top of the stalk, fleshy, three-lobed or parted into three divisions, lanceolate and cut or toothed; veins forking from the midrib; fertile part bi- to tri-pinnate. Plant three to eight inches high.

Mt. Ouray, Colorado (Brandegee). Lake Superior, New England and Europe.

B. Virginianum, Swartz. Sterile portion sessile above the middle of the stalk, thin and papery, divided into three parts, each of which is twice-pinnate at base and twice-parted above. Usually one to two feet high.

Oregon, Washington Territory, also in Colorado and eastward. In various parts of the world.

\section{** Sterile portion long stalked.}

B. ternatum, Swartz. Sterile portion fleshy, many times divided; final divisions from round-kidney-shaped to triangular-lanceolate; fertile portions bi- to quadri-pinnate.

Yellowstone Park (Parry). California, Oregon and various parts of the world.

\section{OPMIOGLOSSUM, Linneus. AddeR's Tongue.}

Sterile portion of the frond (in our plant) entire, net-veined; fertile portion with two rows of spore-cases grown together in a single spike; fronds arising from a bud situated outside of the stalk of the previous season; growing in wet and boggy places.

A genus of about twelve species.

0. vulgatum, L. Sterile portion fleshy, sessile, ovate or elliptical, entire, one to three inches long.

Arizona, Unalaska, eastern States and various parts of the world. Rather rare.

\section{ORDER II.-FILICES.-FERNS.}

Plants with fronds which uncoil as they rise from the rootstock, and produce spore-cases from the epidermis of the under side (in our plants) of the frond. These spore-cases are collected in lines, or round or roundish spots (fruit-dots); they are either naked or covered by an indusium, or by the recurved edge of the frond (involucre). Prothallium growing on the surface of the ground.

A large order of about eighty genera and three thousand species, found chiefly in the tropical regions. Some are used for food, some for their medicinal properties, and many are cultivated for ornament. Ferns are divided into six sub-orders, two of which are represented within our borders-the Polypodiacea with fifteen genera, and the Schizeacea with one genus.

\section{SUB-ORDER I.-POLYPODIACEZ.}

Spore-cases round or flattened somewhat, splitting cross-wise, pro- 
vided with an incomplete ring, by whose contraction in ripening the spore-case is split open and discharges the minute spores.

* Fruit-dots without iudusium or involucre.

$+\quad$ Fruit-dots round or roundish, placed between the midrib and margin on the ends of the veins.

\section{Tribe I.-POLYPODIEZ.-I. Polypodium.}

+ Fruit-dots round, borne on the back of the veins. Indusium none, or minute or on the under side of the frunt-dot, and so not evident.

Phegopteris and Woodsia in Tribe VI.

+++- Fruit-dots either in lines along the veins, or in lines along the tips of the veins close to the margin.

\section{TRIBE II.-GRAMMITHDER.}

2. Gymnogramme.-Fruit-dots in lines along the veins.

3. Notholana.-Fruit-dots clustered at the tips of the veins along the margin, and so running in a more or less interrupted line around the edge.

The margin slightly recurved in N. CANDIDA, N. Grayi, N. Hookeri and so approaching Cheilanthes, but these three species are white- or yellow-powdery beneath ; Cheilanthes never.

** Fruit-dots at the ends of the veins, with involucre at least when young.

\section{TRIBE III.-PTERIIDEE.}

4. Cheilanthes.-Fruit-dots minute, involucre usually not continuous around the final divisions.

Fronds hairy, woolly, or chaffy when the involucre is continuous. Small ferns.

5. Pellara_-Fruit-dots close to the ends of the veins, often running together; involucre thin, continuous around the final divisions. Sterile and fertile fronds much alike, smooth, rather lead-colored; stalk black.

6. Cryptogramme.-Fruit-dots inclined to run down the veins from their tips; involucre broad, light-colored, flattening out as the fern matures. Sterile and fertile fronds unlike; stalk light-colored.

7. Pteris.--Spore-cases borne on what appears to be a vein running across the tips of the veins all around the division of the frond. Involucre continuous. Stalk lightcolored. Large ferns, two to six feet high.

8. Adliantum.-The stalk of the final division (unlike the rest of the tribe) branching at the top into many veins, which run to the edge of the division like the rays of a fan, therefore no midrib. Outer edge of the final divisions recurved, forming the involucre.

*** Fruit-dots with indusium (except Nos. I2 and I5 apparently.) + Fruit-dots borne on the upper side of a veinlet (or a long receptacle which resembles it). Indusium attached to the veinlet and open on the other side, so forming a pocket for the spore-cases.

+ Fruit-dots rather or very long, straight, parallel with the midrib.

\section{TRIBE IV.-BLECHNEAE.}

9. Lomaria.-Fruit-dots running the whole length of the pinnæ. Fertile and sterile fronds pinnate narrow, unlike.

Io. Woodwardia._Fruit-dots short, forming a chain-like row on each side of the midrib. Fronds large, broad.

++ Fruit-dots straight or curved, short, borne on veinlets that are not parallel with the midrib. 
TRIBE V.-ASPLENIEAE.-I I. Asplenium.

++ Fruit-dots round or nearly so, on the backs or occasionally on the tips of the veinlets.

\section{TRIBE VI.-ASPIDIEAE.}

12. Phegopteris.-Indusium none, or very minute; fruit-dots very small, borne on the backs of the veinlets.

13. Aspidium.-Fruit-dots on the back or tip of the veinlets, round or kidneyshaped, opening all around the edge or nearly so.

14. Cystopteris.-Indusium fixed across the back of the veinlets, splitting away at the other side and usually turned back like a hood at maturity. Small and very delicate ferns.

I 5. Woodsia. Indusium fixed beneath the fruit-dot, splitting into several lobes or a delicate fringe, borne on the back of the veinlets. Small plants.

\section{SUB-ORDER II. SCHIZAACEA.}

Spore-cases ovate, opening lengthwise, in two rows.

r6. Aneimia.-Fronds fertile below, sterile above; sterile part long stalked, twice-pinnate, divisions very narrow. Very peculiar plants, not at all like Sub-order I.

\section{TRIBE I.-POLYPODIEA. \\ I.* POLYPODIUM, Linnæus. Polypody.}

Stalk jointed to the chaffy, usually creeping and elongated rootstock. Fronds smooth, and pinnate only in our plants. (The name following Polypodium and all the other genera and species denotes the person who described them.)

Named from the Greek, meaning many feet, in reference to the branching rootstock. A genus of about $35^{\circ}$ species, chiefly tropical, 8 in the United States. Several of our species appear to run together.

* Fronds not divided to or near the midrib; veinlets free.

r. P. vulgare, L. (The common P.)

Fruit-dots rather large, midway between the midrid and margin of the divisions; frond almost leathery (thinner in the var.), oblong in outline, tapering to a point at the top; divisions obtuse or only acute, linearoblong, scalloped, toothed, or almost entire. Plant I to I 2 or more inches high.

In canyons in a few places in Colorado; Cottonwood Canyon, Utah; Oregon and eastward; Europe. Rare in our region.

2. Variety occidentale, Hooker. (The western var.)

Divisions long-pointed and toothed toward the tip. Much larger and thinner than the typical form. Hardly deserves the rank of a variety.

Pacific Coast, San Francisco and northward.

3. P. falcatum, Kellogg. (The hooked P.)

Fruit-dots nearer the midrib than the margin; divisions tapering from a broad base to a slender point, more or less curved and toothed.

* The numbers of the genera in the Key are repreeented here by Roman numerals to avoid confusing the genera and species. 
Veins mostly with four branches. I to 2 feet high. May run into P. vulgare.

Usually on trees. Northern California and northward.

** Fronds divided to the midrib, or very near it; divisions linear-oblong; veinlets usually forming a net-work, at least near the margin.

4. P. Californicum, Kaulfuss. (The Californian P.)

Frond papery, ovate to oblong-lanceolate; divisions narrowed at base, but not stalked, upper ones gradually smaller till they become mere teeth at the tip of the frond; veinlets 4 to 6 , the lowest one bearing an elliptical or egg-shaped fruit-dot, the upper ones sometimes sending branches across to each other close to the margin, making a net-work. Varies greatly. ( $P$. intermedium, H. \& A.)

From Guadalupe Island northward, mostly along the Coast.

5. P. Scouleri, Hooker and Greville. (Scouler's P.)

Fronds very thick, leathery, fleshy when green, broadly ovate; divisions minutely toothed, blunt, not tapering into the terminal one; fruit-dots very large (often one-fifth inch in diameter), near the midrib; veinlets forming a series of meshes all along the margin. (P. carnosum, Kellogg; P. pachyphyllum, Eaton.)

On stumps and trees, rarely on the ground. Guadalupe Island to British America.

\section{TRIBE II.-GRAMMITIDEE. \\ iI. GYMinOGRAMME, Desvaux. Gold Fern.}

Fruit-dots oblong or linear, and like the veins either undivided or forked. Fronds pinnate, in our plants three to five angled; lower pinnæ twice-parted, nearly as broad as long. Distinguished from Notholæna also by the fine lines of spore-cases that run from the margin to the midrib like veins, in fronds that are not too mature.

A large genus, two species in the United States. The name,taken from the Greek, meaning naked spores, in allusion to the lack of indusium.

6. G. triangularis, Kaulfuss. (The three cornered G.)

Fronds smooth or granular above in the typical form, densely covered beneath with a beautiful yellow or white powder: stalks darkbrown, polished.

Shaded hillsides; California to Vancouver Island; common. Ecuador.

7. Variety viscosa, Eaton. (The viscid var.)

Frond viscid above.

Southern California.

8. G. hispida, Mettenius. (The stiff-hairy G.)

Frond covered with long, stiff hairs above, woolly and minutely scaly beneath: stalks grayish, minutely pubescent. (G. podophylla, Hooker; G. pedata, Eaton, Rob. Cat.)

New Mexico and Arizona.

III. NOTHOLAENA, R. BROwN. ROCK FERN.

Fruit-dots roundish or oblong, soon running together and forming a 
continuous line. Small ferns. Fronds pinnate to quadri-pinnate; lower surface almost always hairy, woolly, chaffy, or powdery. Distinguished from Gymnogramme by the spore-cases being on the margin only, not running up the veins to the midrib, in young fronds. Distinguished from Cheilanthes, on the other hand, by the spore-cases not being covered by an involucre. In three cases, $N$. candida, $N$. Hookeri, and $N$. Grayi the margin is recurved, but not so as to cover the spore-cases; and these three species are white or yellow-powdery beneath ; our species of Cheilanthes are never powdery.

Probably from the Greek, meaning spurious involucre, from the slightly recurved margin in some of the species.

A genus of about 40 species, I I in the United States, all western. Growing in dry, rocky places.

\section{* Frond scaly beneath.}

9. N. sinuata, Kaulfuss. (The wavy-margined N.)

Fronds pinnate, stiff and narrow; pinnæ almost entire, or lobed, ovate or roundish; upper surface sprinkled with stellate hairs or divided scales. 6 to 24 inches high. ( $N$. levis, Mart. \& Gal.; $N$.pruinosa, Fee.)

Texas to Arizona, south to Chili.

* Frond hairy above, densely woolly beneath.

го. N. ferruginea, Hooker. (The rusty N.)

Fronds pinnate, narrowly lanceolate; pinnæ from $1 / 3$ to $1 / 2$ inch long, divided into 6 to 8 small lobes on each side. ( $N$. rufa, Presl.)

Arizona to Texas, south to Ecuador.

r I. N. Parryi, Eaton. (Parry's N.)

Fronds thrice-pinnate; final divisions I-I'2 inch long.

Resembles Cheilanthes lanuginosa. Clefts of rocks, southern Utah to California.

I 2. N. Newberiovi, Eaton. (Newberry's N.)

Frond thrice- to quadri-pinnate; final divisions I-24 inch long. Very near to No. I $\phi$, but with a much finer and denser wool.

Southern California to Guadalupe Island.

*** Fronds white- or yellow-powdery beneath; (also scaly in No. I8.)

+ Fronds pinnate only, green above; the pinna not stalked; margin of the frond slightly recurved as in Cheilanthes, but not so as to cover the sporecases. Plants a foot high. Stalks smooth and shining.

I 3. N. candida, Hooker. (The shining N.)

Fronds triangular or ovate: lowest pinnæ elongated, their lowest divisions again divided; upper pinnæ scarcely separate, passing into mere lobes at the top, green above, and white- or yellow-powdery beneath; midrib blackish. ( $N$. sulphurea, Smith; $N$. pulveracea, Kunze.)

Texas to California, south to Chili. Known under many names.

I 4. Nookeri, Eaton. (Hooker's N.)

Frond distinctly five-sided, ternate; the middle division stalked, the other two sessile, and having on the lower side of each a long, lobed division, making the trond appear to be divided into five parts. Powder 
pale-yellow. Resembles Gymnogramme triangularis. ( $N$.cretacea, Eaton, Bot. Mex. Bound; N. candida var. 5-fido-palmata, Hooker.)

Texas to New Mexico.

+- Frond bi-to quadri-pinnate; pinne stalked.

++ Frond not less than tri-pinnate; pinnce rather long stalked; final divisions oval or elliptical, entire or three-lobed, very small; powder white: stalks very dark, polished, tufted.

I5. N. dealloata, Kunze. (The whitened N.)

Frond triangular-ovate, quadri-pinnate at base; pinnæ chiefly opposite; rachis straight; final divisions $\mathbf{I}-24$ to $\mathbf{I}-\mathbf{I} 2$ inch long. (Cheilans thes —, Pursh.)

Kansas to Arizona; on dry, precipitous, chalky rocks.

I6. N. mivea, Desvaux. (The snowy N.)

Frond triangular-ovate, tri-pinnate; pinnæ mostly opposite, rachises nearly straight, final divisions ovate or oval, obtuse, entire or lobed, smooth and green above, densely white-powdery beneath: spore-cases brown, often running half-way down the veinlets. Stalks black and shining.

Tombstone Mine, Arizona; Mexico.

\section{7. N. Fendleri, Kunze. (Fendler's N.)}

Fronds often almost five times pinnate; pinnæx alternate; rachis and all its branches bent in a zigzag, tangled way; final divisions I-I 2 to $\mathbf{I} / 8$ inch long, often white-dotted or glandular above.

Clefts of rocks, occurring as high as 8 ,ooo feet above the sea. One of the most beautiful ferns. Colorado to New Mexico and Arizona.

+++ Fronds narrowly lanceolate, bi-pinnate; pinne very short stalked, lower ones distant; final divisions linear or oblong, not minute.

I8. N. Lemmoni, Eaton. (Lemmon's N.)

Stalks, rachis and all its branches black, shining, almost smooth; pinnæ $3 / 4$ inch long, broadly triangular; lower pinnules linear, parted or lobed, upper scalloped and passing into mere lobes of the pinnæ; powder yellowish; spore-cases scanty.

Southern Arizona. A very recent discovery.

I9. N. Grayi, Davenport. (Gray's N.)

Stalks cinnamon-colored, minutely pubescent and glandular, and with scattered, awl-shaped, lacerate, long-acuminate, cinnamon-colored scales, which extend to the midrib of the pinnules also; pinnæ $1 / 2$ inch or less long; pinnules broadly oblong, white-powdery beneath, margin slightly lacerate and beautifully white-powdery on the upper side; sporecases very abundant.

Southern Arizona. A very recent discovery.

**** Frond without scales, powder, hair, or wool.

20. N. tenera, Gillies. (The delicate N.)

Frond pinnate to tri-pinnate, almost leathery, ovate-triangular; pinnæ chiefly opposite, distant; final divisions ovate or almost heartshaped, about I-I 2 inch long. Six inches or more high.

In clefts of precipitous rocks. Southern Utah, near St. George, (Parry \& Palmer). Very rare. Also in Bolivia and Chili. 


\section{TRIBE III.-PTERIDEE.}

\section{iV. CHEULAN'THES, Swartz. Lip-Fern.}

Fruit-dots not very evident. Involucre almost always broken up by the cuts or lobes on the final divisions, often with a whitish papery prolongation. Final divisions very minute or small. Bi- to quadri-pinnate ferns. (See Notholena for three exceptional species.)

Sixty species in the United States. Growing in the clefts of rocks. Some species approach Notholæna very closely, but the margin is always slightly recurved, at least. Greek lip-flower, from the shape of the indusium.

* Involucres situated between the teeth of the final divisions.

2r. C. Californica, Mettenius. (The Californian C.)

Fronds quadri-pinnate, very broadly ovate, smooth; all the rachises but the primary one winged; lower pinnæ more developed on the lower side; final divisions lanceolate, cut or toothed, very acute, teeth often recurved; involucres crescent-shaped, thin and papery. (Hypolepis Hooker.)

Damp and shady canyons along the coast; Santa Cruz, California to Sonora, Mexico.

** Involucres not situated between the teeth of the final divisions, extending over the tips of several veinlets, but not in an unbroken line all around the final divisions.

+ Frond not glandular, usually smooth.

+t+ Frond bright green, pinnate; pinna twice-parted, but not divided.

22. C. Wrightii, Hooker. (Wright's C.)

Fronds ovate-oblong; pinnæ about five pairs, deltoid, distant. Stalk black. 3 to 5 inches high.

Arizona, New Mexico and Texas.

+++ Fronds bi- or tri-pinnate. Texture firm. 6 to 12 inches high.

23. C. microphylla, Swartz. (The small leaved C.)

Frond often tri-pinnate, smooth or slightly pubescent, broadly lanceolate; lowest pair of pinnæ the largest ; final divisions deeply cut: stalks dark-brown, rusty-pubescent on the upper side: involucre of the same color as the frond.

Florida, Arkansas and New Mexico; south to Chili; common in the West Indies.

24. C. Alabamensis, Kunze. (The Alabama C.)

Frond bi-pinnate, narrowly lanceolate, nearly smooth; lowest pair of pinnæ not larger than those next above; final divisions with a little lobe on one side, or, in larger specimens, with several lobes or teeth: stalks black, smooth, woolly at base: involucre light colored, papery. Closely resembles No. 23. (Pteris —, Buckley; Pellaa —, Baker.)

Texas to Alabama and Virginia.

++ Frond very glandular and sticky, not hairy.

25. C. viscida, Davenport. (The sticky C.)

Frond narrowly oblong, pinnate; pinnæ 4 to 6 pairs, distant, nearly sessile, broadly triangular, twice parted; divisions toothed, the teeth 
recurved and covering one to three spore-cases. 6 to Io inches high. Makes a very close approach to Notholæna.

Eastern side of the Sierras at San Gorgonio Pass, California, (Parry).

+++ Frond glandular and evidently hairy, not woolly.

26. C. lencopoda, Link. (The white-powdery C.)

Frond deltoid-ovate, quadri-pinnate at base, simpler upwards ; lowest pair of pinnæ deltoid-ovate, the upper oblong; pinnules stalked, oblong: final divisions minute and rounded; when fertile, with a strongly recurved margin. Pubescence short and glandular. Stalks straw colored. 6 to 7 inches high.

New Mexico, Texas and Mexico. Rare.

27. C. viscosa, Kaulfuss. (The glutinous C.)

Has a nearly black stalk, and smaller and stiffer frond; otherwise as No. 26. May occur in New Mexico or Arizona.

\section{C. Cooperre, Eaton. (Mrs. Cooper's C.)}

Frond ovate-lanceolate, bi-pinnate; pinnæ oblong-ovate; pinnules roundish-ovate, scalloped and cut, the ends of the lobes recurved when young, unrolled afterwards and exposing the spores. Stalk and frond with whitish, jointed, often gland-tipped hairs. Closely resembles $C$. vestitc of the eastern States, but that is devoid of gland-tipped hairs.

Santa Barbara, Sierra Valley, etc., California.

*** Involucre extending in an unbroken line all around the rounded, minute, final divisions. Fronds bi-to tri-pinnate, scaly or woolly.

+ Frond densely woolly beneath, not evidently scaly, pubescent above, thrice-pinnate in well developed specimens. Stalks woolly. Involucre narrowe.

\section{C. lanuginosa, Nuttall. (The woolly C.)}

Frond hairy above, or nearly smooth, ovate-lanceolate; lowest pinnæ deltoid; final divisions I-24 inch long and broad, the one on the end of the pinnæ or pinnules slightly longer than broad; involucre very narrow, of the same color as the frond. 4 to 8 inches high. (C. lanosa, Eaton; C. gracilis, Mettenius.)

Illinois to the Oquirrah Mountains, Utah; south to Arizona; north to British America.

3o. C. tomentosa, Link. (The matted-woolly C.)

Frond woolly above, oblong-lanceolate; pinnæ ovate-oblong; final divisions nearly round, I-24 to I-I 6 inch long, the one on the end of the divisions twice larger; involucre light-colored, papery. 12 to 24 inches high.

Texas to North Carolina.

++ Frond woolly and scaly beneath.

+ Frond scaly only on the rachis and its branches. Stalks scaly when young, not hairy.

\section{C. Hatoni, Baker. (Eaton's C.)}

Frond oblong-lanceolate, tri-pinnate, woolly above, wool often very dense; final divisions I-24 inch long, rounded, the terminal one often twice as large and obovate; involucre very narrow, hidden by the reddish- 
yellow wool. Scales entire. 6 to 18 inches high. (C. tomentosa, Hooker.) South from Manitou (Colorado) to Texas and Arizona.

\section{C. gracillima, Eaton. (The very slender C.)}

Frond smooth above, or nearly so, linear-oblong, bi-pinnate ; pinnæ with about nine oblong-oval pinnules which are about I- 2 inch long and covered beneath with pale, reddish-yellow, matted wool; involucre yellowish-brown. Scales entire. Rootstock many branched, forming a tangled mass. 4 to 8 inches high. (C. vestita, Brackenridge, U. S. Expedition.)

From the Yosemite (California) to British Columbia, and westward to the coast.

33. C. Parishii, Davenport. (Parish's C.)

Frond scantily long-woolly on both sides, oblong-lanceolate; pinnæ ovate-oblong; final divisions three-lobed; involucre very narrow, scarcely concealing the spore-cases. Scales jagged or toothed on the edges. Rootstock short. 7 to ro inches high. Resembles No. 29.

Near San Bernardino, California. A recent discovery.

++++ Divisions scaly beneath as well as the stalk, rachis and its branches. Involucre very evident.

\section{C. myriophylla, Desvaux. (The many-leaved C.)}

Rootstock very short, its scales narrow, stiff, dark-brown. Frond oblong-lanceolate, almost smooth above, densely scaly and woolly beneath; scales hairy on the margin, those on the final divisions having long, twisted hairs; final divisions innumerable, I-24 inch long, roundish, crowded. 5 to $\mathrm{I} 4$ inches high. (C. elegans, Desv.; C. paleacea, Mart. and. Gal.)

Lake County (California) to Nevada; south to Chili. India.

\section{C. Lindheimeri, Hooker. (Lindheimer's C.)}

Rootstock slender, elongated, branched; its scales ovate and rusty. Frond ovate-lanceolate, upper side white-woolly; final divisions roundishpear-shaped, I-48 inch broad. Scales of the rachis and its branches hairy at base, those on the final divisions gradually passing into wool.

Arizona to Texas.

+++ Frond scaly only, tri-pinnate, ovate-lanceolate, smooth above; final divisions $\mathrm{I}-24$ inch broad.

\section{C. Fendleri, Hooker. (Fendler's C.)}

Scales of the rachis like those on the stalk, slender, minute; those on the rest of the frond broadly-ovate, brown, margin white, not hairy on the edge, overlapping each other and the minute (less than I-24 inch long), beaded, round, final divisions; each division usually with one broad scale: involucre very prominent. 5 to 9 inches high.

Glen Eyrie (Colorado) to Texas and Arizona.

\section{C. Clevelandii, Eaton. (Cleveland's C.)}

Scales densely crowded, ovate, tapering to a sharp point, cinnamonbrown, half as large as those in No. 36 , beautifully hairy on the edge; final divisions nearly round, flattish: involucre narrow. 6 to I 2 inches high.

Near San Diego, California; also in Lower California.

C. ARgentea, Kunze. (The silvery C.) Is reported from Alaska. 


\section{PELI $\mathbb{A}$ A, Link. Cliff-Brake.}

Fruit-dots oblong or roundish, soon running together. Small ferns. (Greek dusky, from the dark stalk.)

A genus of about 50 species. Most of them in South Africa; some in tropical America, and II in the United States.

\section{* Fronds pinnate, smooth, thin; veins easily seen; involucre broad.} Rootstock short.

\section{P. Breweri, Eaton. (Brewer's P.)}

Pinnæ entire, or two-lobed or parted, oblong-ovate; veins more than once-forked. Stalks breaking up into many joints. Involucre lightcolored. Sterile pinnæ broader. Rootstock very short and thick.

California and Arizona to Utah and southern Colorado. Clefts of rocks.

39. P. gracilis, Hooker. (The slender P.)

Frond very thin and delicate; lower pinnæ once- or twice-parted into three to five divisions; ferti.e divisions oblong or linear-oblong, entire or sharply cut; divisions of sterile fronds obovate or ovate, scalloped or cut; veins of the fertile fronds usually once-forked. Rootstock very slender. Stalks not breaking into joints. 3 to 6 inches high.

On shaded limestone rocks. Vermont to Colorado. Asia. Rare in the West.

** Fronds leathery; veins not easily seen; involucre very evident.

+ Final divisions obtuse or acute, not having a sharp point or prickle at the tip.

\section{$\rightarrow$ Fronds never tri-pinnate.}

40. P. atropurpurea, Link. (The dark purple P.)

Smooth, except a few hairs on the stalk and midrib. Frond pinnate (lower pinnæ sometimes pinnate): fertile divisions linear or oblong; sterile sometimes oval, usually entire, slightly heart-shaped or truncate at base; veins forking only twice. 6 to 18 inches high. (Pteris -, L. ; Allosorus —-, Kunze.)

Clefts of perpendicular rocks. Colorado (rare), to Arizona and Mexico. Throughout the eastern States.

\section{4r. P. aspera, Baker. (The rough P.)}

Frond bi-pinnate, very rough on both sides with short, stiff, straight or branched white hairs; pinnæ and pinnules deltoid-lanceolate; edges of the involucre scalloped. 6 to 9 inches high. Hooker.)

New Mexico to Texas.

Fronds tri-to quadri-pinnate. (No. 42 is rarely bi-pinnate.)

42. $\quad$ P. andromedæfolia, Fee. (The Andromeda-leaved P.)

Rootstock slender. Frond ovate, chiefly tri-pinnate; final divisions 2 -I 2 to 5-I 2 inch long, oval, slightly heart-shaped, notched at the end, otten sessile, almost fleshy; fertile divisions often with the edges rolled up to the midrib; veins numerous, parallel ; involucres thin, white-margined. 4 to 24 inches high. (Pteris — and Allosorus —-, Kaulfuss.) California to Arizona. Chili. South Africa.

43. Variety pubescens, Baker. (The pubescent var.) Final divisions usually larger than in the typical form, and often 
more heart-shaped; rachis finely pubescent and almost glandular.

San Diego (California), Arizona, New Mexico. Rare.

\section{P. pulchella, Fee. (The pretty P.)}

Rootstock very short. Frond quadri-pinnate at base, triangularovate; final divisions ovate-heart-shaped, obtuse, I-I 2 to I-4 inch long, always stalked, smooth, edges often much rolled up; involucre thin. Rachis and all its divisions black, polished. 6 to 18 inches high. ( $A l$ losorus —, Mart. \& Gal.)

New Mexico to Peru.

++ Final divisions very sharp-pointed or prickly.

45. P. ternifolia, Link. (The P. with leaves divided in threes.)

Fronds pinnate; lower pinnæ three-parted.

May occur in Texas or Arizona. Mexico to Peru.

+ Rootstock short and thick. Frond bi-pinnate, smooth; fertile pinnules rolled up to the midrib.

46. P. Wrightiana, Hooker. (The P. dedicated to Wright.)

Pinnules spreading, not exceeding six pairs; sterile ones broadly oval, nearly $1 / 2$ inch long, rounded or heart-shaped at base, obtuse but with a minute, sharp point or prickle. Fronds lanceolate. Scales on the rootstock dark-brown. 8 to $\mathrm{I} 2$ inches high. ( $P$. mucronata, Baker; $P$. Weddelliana, Fee.)

Colorado to Texas, Arizona and California.

47. P. brachyptera, Baker. (The small fern.)

Pinnæ very short, often broader than long, ascending or pressed close to the rachis; pinnules 5 to $\mathrm{I} 3$ to each pinna, $\mathrm{T} / 4$ to $\mathrm{x} / 2$ inch long, crowded; frond narrowly oblong-linear. Scales on the rootstock rusty, toothed. I 2 to 18 inches high. ( $P$. Ornithopus, var. - Eaton.)

Sierras, California. Rocky places.

+++ Fronds tri-pinnate (in well developed plants).

48. P. Ornithopus, Hooker. (The bird-footed P.)

Fronds very stiff; pinnæe linear, lower ones often $1 / 3$ the length of the frond; pinnules with 3 to 7 divisions, not exceeding $1 / 6$ inch long, margins rolled up to the midrib, the rare sterile divisions four-sided. Rootstock very thick and short. Island.

Dry, rocky hillsides; throughout California, especially near the coast. Guadalupe

49. P. densa, Hooker. (The close-set P.)

Ruotstock slender, branching, tangled. Frond ovate, I $\mathrm{x} / 2$ to $2 \mathrm{r} / 2$ inches long: final divisions $\mathrm{x} / 2$ inch long, linear-lanceolate; fertile entire. sterile sharply toothed; margins slightly recurved: involucre lightcolored. Usually very small, growing at high elevations. (Onychium - Brackenridge.)

Utah and western Wyoming to California and Oregon. Rocky places.

*** Fronds leathery; veins hidden; final divisions broad and flat; involucre very narrow.

50. P. Bridgesii, Hooker. (Bridges' P.)

Fronds pinnate; pinnæ mainly opposite, sterile ones round, at first 
folded together and so half-moon-shaped, glaucous; involucre narrow, whitish, soon unrolled and exposing the spore-cases. Stalks dark-brown. Scales on the rootstock very narrow, upper half or two-thirds hair-like, often cleft. 6 to $\mathrm{x} 2$ inches high.

Crevices of rocks. Sierras, California.

5 r. P. flexuosa, Link: (The easily bending P.)

Fronds bi- or tri-pinnate; final divisions broadly ovate or heartshaped, very obtuse; involucre at length flattened out and exposing the spore-cases. Rachis and its branches bent in a zigzag way. Stalks reddish. 6 to 24 inches or more long. (Allosorus -, Kaulfuss; P. intermedia, Kuhn.)

Texas to Arizona; south to Peru.

\section{CRYPTOGRAMME, R. BRown. Rock-B̈RAKE.}

Fruit-dots round or oblong, soon running together. Fronds smooth; the sterile ones with ovate or obovate toothed or cut divisions, tri- to quadri-pinnate; fertile ones taller than the sterile, long-stalked, less divided; the divisions linear or oblong-linear, pod-like. Occasionally the upper part of the fertile frond is sterile. (Greek for hidden-spores.)

A genus of two species, one American and one European.

52. C. acrostichoides, R. Brown. (The Acrostichum-like C.)

Sterile fronds leathery, dark-green, scalloped or toothed; fertile yellowish and thinner. (Allosorus —-, Sprengel.)

In dense tufts among rocks. California to Colorado and Lake Superior; north to latitude $56^{\circ}$ or $60^{\circ}$. It has been found growing above timber line (I 2,000 feet above the sea) in Colorado.

\section{PTERIS, Linneus. Brake. Bracken.}

Fronds in our species large; veins free. (Greek wing, because the fronds are pinnate, feather-like.)

A large genus, chiefly tropical. A very few species in the southern States.

\section{P. aquilina, Linnæus. (The P. like an eagle's beak.)}

Frond 2 to 3 feet long and broad, almost leathery, smooth in the typical form, bi- to quadri-pinnate at base; lowest pinnæ rather longstalked; pinnules oblong-lanceolate or linear-halberd-shaped, entire or pinnately parted: final divisions oblong or linear, obtuse; terminal ones rather long, tapering: veins much forked. Stalks solitary, erect, lightcolored, naked, swollen at base. Rootstock large, thick, having the partly decayed woody remains of the stalks of previous seasons.

Throughout the United States; less common westward. Various parts of the world. In wet or damp places. Young fronds and rootstocks often used for food.

54. Variety lanuginosa, Bong. (The woolly variety.)

Lower side of fronds silky or woolly; final divisions broad.

Common in California, east to Colorado. Merely a western form of the species. Very often grows on dry hillsides, and is six feet high. 


\section{ADIANTUM, Linnæeus. Maiden-Hair.}

Chiefly smooth ferns, $\mathrm{I}$ to $2 \mathrm{~T} / 2$ feet high, of graceful aspect. Stalk black, polished. Final divisions never narrow. (Greek unwetted, the fronds shed rain because they are oily.)

A genus of 67 species, mostly tropical.

* Stalks forked.

55. A. pedatum, L. (The A. like a foot.)

Rachises bearing, on the outside, 6 to I 4 pinnate divisions; pinnules oblong, lobed or cleft, short-stalked; main vein running along the lower side of the pinnule which therefore appears one-sided.

Common in the coast ranges; less frequent in the Sierras, where it reaches an altitude of 7,00o feet at Summit (Jones.) Very rare in the Rocky Mountains (Cottonwood Canyon, Utah; Watson). North to Unalaska and east to the Atlantic. Japan, etc.

** Stalks not forked. Fronds ovate to oval in outline, bi- to quadripinnate at base, simpler upwards.

56. A. Capillus-Veneris, L. (Latinized Maiden-Hair.)

Final divisions wedge-shaped at base with nearly straight sides, obovate or broader, scalloped and finely toothed; involucres separated, oblong. Fronds delicate, smooth, usually drooping, upper half or third only pinnate.

Around springs and in damp canyons; southern California, Arizona, southern Utah, southern States and various parts of the world.

57. A. emarginatum, Hooker. (The notched A.)

Final divisions smooth or nearly so, almost semi-circular, sometimes wedge-shaped at the very base; sides concave, slightly cut; involucres almost continuous. Stalks rather stout. Not drooping.

In canyons; from San Diego (California) to Oregon, in the coast ranges.

58. A. tricholepis, Fee. (The velvety A.)

Final divisions hairy on both sides; involucres very velvety. Rootstock creeping; with linear, acuminate, tawny scales.

Rocky ravines. Western Texas to Yucatan. May have been collected by Nuttall at Monterey, California.

\section{TRIBE IV.-BLECHNEÆ.}

\section{ix. homa Ria, Willdenow. Deer-Fern.}

Sterile fronds with pinnæ rather broad; veins free. Fertıle fronds with very narrow pinnæ; veins often forming a series of meshes on each side of the midrib. (Greek for a border, on account of the long indusium?)

A genus of about 45 species, chiefly tropical. Evergreen.

59. I. Spicant, Desvaux. (The pointed L.)

Sterile fronds smooth, almost linear, tapering at both ends; stalk scarcely any; pinnæ oblong or oblong-linear, curved upwards. Fertile fronds very narrow, long-stalked; pinnæ sessile by an abruptly widened 
base. Rootstock short, thick, chaffy. 2 to 3 feet high. (Osmunda-, L.; Blechnum boreale, Swartz.) liar fern.

Damp canyons; Santa Cruz (California) to Oregon, in the coast ranges. A pecu-

6o. Variety serratum, Wollaston. (The toothed variety.)

Margins strongly aud doubly serrate.

Deep ravines, Multoonal Co., Oregon (Howell).

A very peculiar form (Blechmum doodioides, Hooker), found in British Columbia, had the lower half of the fronds sterile and the upper half fertile, and the fruit-dots broken up into several short ones on each pinna.

\section{WO0DWARDia, Smith. Chain-Fern.}

Veins forming oblong meshes on each side of the midrib, at least. Tall ferns. Dedicated to Woodward.

A genus of 5 or 6 species. Two or three Asiatic, the rest American.

6r. W. radicans, Smith variety Americana, Hooker. (The rooting A., American variety.)

Fronds pinnate, almost leathery ; pinnæ parted ; 8 to $x_{5}$ inches long, 2 to 4 wide; final divisions triangular-lanceolate, curved, acuminate, spiny-toothed; fruit-dots close to the midrib. Rootstock stout, rising somewhat above the ground. 4 to 6 feet high. (W. Chamissoi, Brackenridge; $W$. spinulosa, Martens.)

Mendocino County (California), southward in the coast ranges and the Sierras; extending to Guatamala. The typical European form has a bud at the tip of the frond.

\section{TRIBE V.-ASPLENIEÆ. \\ XI. ASPLENIUM, Linneus. SPleEnwort.}

Fruit-dots sometimes on the lower side of the veinlets also. Veins free in our species. (Greek against spleen, because of their reputed remedial qualities.)

A genus of 300 species; 18 in the United States.

* Indusium straight. Fronds pinnate; pinne very numerous, almost sessile. Small ferns.

62. A. Trichomanes, L. (The A. like Trichomanes.)

Stalks I to 5 inches long, nearly black, and narrowly winged as well as the rachis. Fronds 2 to 8 inches long, evergreen, linear, rather rigid; pinnæ round, oval or oblong; base wedge-shaped or truncate, entire or minutely scalloped; fruit-dots 3 to 6 on each side of the midrib; indusium very delicate, scalloped or entire. Rootstock thick and short.

Clefts of rocks. Rare in the west. California, Colorado, Oregon, Washington Territory. Common in the eastern States. Throughout the temperate zone.

63. Variety incissim, Moore. (The cut variety.)

Pinnæ cut-lobed; lobes often scalloped.

Southern California.

64. A. parvulum, Martens and Galeotti. (The very small A.)

Stalks short. Fronds almost linear, stiff-papery; pinnæ very many, 
oblong, small, entire or minutely scalloped, enlarged at the base on the upper side, middle ones largest, lower smaller and bent down. 4 to 8 inches high. (A.trichomanoides, Mett.; A. ebeneum, Eaton, Mex. Bound.)

Texas to Florida. Rare. Resembles A. ebeneum closely.

65. A. viride, Hudson. (The green A.)

Stalks reddish-purple at base; rachis green, narrowly winged, with a few black hairs: frond linear, not evergreen, thin ; pinnæ very broadly ovate or oblong, deeply scalloped; fruit-dots $\mathrm{x}$ to 3 on each side of the midrib. Rootstock slender, creeping. Scales at base of the stalk lanceolate, acuminate, with beautiful black striæ and meshes.

Northern Rocky Mountains and eastward. Clefts of rocks.

66. A. septentrionale, Hoffmann. (The A. of the north.)

Fronds in dense tufts, grass-like; with 2 to 5 long-linear, acute divisions. Fruit-dots long, two or three to a division, next to the margin. 2 to 4 inches high. Closely resembles a bunch of grass: unlike any other fern of our region.

Colorado and New Mexico. Europe and India. Rare.

* Fruit-dots usually curved or horse-shoe-shaped. Large ferns.

67. A. Filix-fomina, Bernhardi. (Female-Fern.)

Fronds once- to tri-pinnate, thin, acuminate; fruit-dots near the midrib. 2 to 4 feet high.

Variety angustum, Eaton. (The narrow variety.)

Fronds almost bi-pinnate; pinnæ lanceolate, bent upwards ; divisions oblong, scalloped or toothed. Fruit-dots very many. I to 3 feet high.

California, Utah and eastward. In damp, shady places.

68. Variety latifolium, Hooker. (The broad-teaved variety.)

Frond almost bi-pinnate, oblong-lanceolate; pinnæ oblong-linear. Secondary rachis winged. Final divisions broadly ovate, obtuse, often doubly serrate, 2 to 3 feet high.

Oregon. In damp, shady places.

69. Variety commume, Eaton. (The common variety.)

Frond bi-pinnate; pinnæ long; pinnules oblong-lanceolate, pointed, cut or serrate. About 2 feet high.

Throughout the United States. Damp, shady places.

7o. Variety cyclosorum, Ruprecht. (The variety with rounded
fruit-dots.)

Fronds very large, about 5 feet high, bi-pinnate; pinnules almost parted; fruit-dots roundish; indusium very short, small.

Oregon and Vermont. Damp, shady places.

\section{TRIBE VI.-ASPIDIEÆ.}

\section{XiI. PHEGOPTLRIS, Fee. Beech-Fern.}

Stalks not jointed to the rootsitock. Our ferns have free veins; fruitdots near the margin; fronds very thin and papery, bright-green. This was formerly united with Polypodium. (Greek for beech-fern.)

A_genus of about Ioo species, 4 North American. 
* Fronds pinnate, or several times parted.

7 I. P.alpestris, Mettenius. (The alpine P.)

Fronds oblong-lanceolate, acuminate, smooth, pinnate ; pinnæ twiceparted, deltoid-lanceolate; final divisions from ovate-oblong to lanceolate, twice cut or toothed. Rootstock short and thick. I to 3 feet high, (Polypodium —-, Hoppe ; Aspidium —-, Swartz.)

Around rocks in dense patches; Lassen's Peak (California) to British Columbia. Europe. Resembles Asplenium Filix-fœmina.

72. P. polypodioides, Fee. (The P. like Polypodium.)

Fronds twice-parted, deltoid-ovate, hairy on the veins; lowest pair of primary divisions turned downwards; final divisions oblong, entire, obtuse. Rachis winged. Rootstock very slender. 8 to 18 inches high. (Polypotium Phegopteris, L.)

Damp woods. Said to occur at San Jose (California). In the Rocky Mountains and eastward. Alaska. Europe and Asia.

** Fronds divided into three stalked, once-or twice-pinnate divisions.

73. P. Dryopteris, Fee. (The P. like Dryopteris. Oak-Fern.)

Fronds smooth; divisions triangular; final divisions oblong, toothed or entire, obtuse. (Polypodium - L.)

Damp woods. Oregon and eastward.

\section{XiII. ASPIDIUM, Swartz. Shield-Fern. Wood-Fern.}

Indusium attached to the center of the fruit-dot by a short stalk, or attached on one side at the margin. Veins free in our species. (From the Greek, meaning a little shield, in allusion to the indusium.)

A genus of over 300 species, chiefly tropical; 23 species in the United States.

* Indusium kidney-shaped or round, fixed by one side.

+ Veins forking but once. Thin or papery ferns. Fronds pinnate; fruitdots close to the margin. Rootstock thick, creeping.

\section{A. Nevadense, Eaton. (From the Sierra Nevadas.)}

Stalks short. Fronds narrowly lanceolate, pinnate; lower pinnæ gradually reduced in size, linear-lanceolate, broad at base, almost sessile, deeply cut; final divisions oblong, nearly entire, obtuse, somewhat hairy on the veins, resinous dotted; indusium minute, hairy, glandular. 2 to 3 feet high.

Shady and moist places in the Sierras of California. Resembles A. Noveboracense, except in the rootstock.

\section{A. patens, Swartz. (The open A.)}

Fronds ovate-oblong, softly pubescent; lower pinnæ not reduced, linear, acuminate, pinnately parted; final divisions oblong, somewhat acute; indusium very pubescent. I to 3 feet high. (Nephrodium Desvaux.)

In canyons; southern California, Texas to Florida and southward. Polynesia and South Africa.

++ Veins forking freely; frond not papery; rachis usually scaly, as well as the stalk. Rootstock short and thick. 
76. A. frrggrons, Swartz. (The fragrant A.)

Frond pinnate, narrowly lanceolate, glandular, fragrant, small; pinnæ parted, linear-oblong; final divisions oblong, obtuse, usually toothed, almost covered beneath with very large over-lapping indusia which are round and glandular on the edge. 4 to I 2 inches high.

Northern Rocky Mountains and eastward.

77. A. Fillix-mas, Swartz. (The Male-Fern.)

Frond once- to twice-pinnate, smooth, broader; pinnæ lanceolate, acuminate from a broad base; final divisions oblong, obtuse, toothed at the tip, lower ones cut; fruit-dots large, near the midrib; indusium smooth, round-kidney-shaped. I to 3 feet high. (Nephrodium Richard.)

In damp canyons. Rare. Colorado and northward, thence eastward. In various parts of the world.

78. A. rigidum, Swartz, variety argutum, Eaton. pungent variety.)

Fronds bi-pinnate, ovate or triangular-lanceolate, smooth, glandular beneath; pinnæ oblong-lanceolate, the lowest broadest; final divisions oblong, cut or doubly serrate, teeth tipped with small bristles; veins very prominent; fruit-dots large, nearer the midrib than the margin; indusium round, glandular around the edge. Dried fronds fragrant. I to 3 feet high. (A. argutum, Kaulfuss.)

Shaded canyons and hillsides. Oregon to Mexico, chiefly in the coast ranges.

79. A.spinulosum, Swartz, variety dillatatum, Hornemann. (The bristly A., dilated variety.)

Frond bi- to tri-pinnate, ovate; pinnules toothed or cut, lanceolateoblong, set obliquely on their winged rachis; lobes bristly toothed; indusium small, smooth. Scales on the stalk brown, with a dark center. I to 3 feet high. (A. dilatatum, Swartz.)

Damp woods; Oregon and eastward.

A. Oreopteris, Sav., occurs in Unalaska, but does not reach our limits.

** Indusium round, fixed by the center.

+ Fronds bristly toothed; pinna enlarged at the base on the upper side. +- Fronds pinnate, leathery; pinne only toothed (cut only in No. 84); veins not uniting at the tip.

8o. A. Honchitis, Swartz. (The spear-like A.)

Fronds scarcely stalked, linear-lanceolate, very stiff and leathery; pinnæ lanceolate, curved, an inch long, teeth dense and long, bristletipped; fruit-dots touching each other and near the margin. 9 to 20 inches high.

Usually at high altitudes, along streams and in clefts of wet rocks. Colorado, Utah, British Columbia and eastward. Europe and Asia. Not common.

81. A. munitum, Kaulfuss. (The armed A.)

Stalks often a foot long. Fronds lanceolate, almost leathery; pinnæ linear-acuminate, 3 to 4 inches long, sharply and doubly serrate; bristles pressed close to the frond and pointing forward. In the typical form the fruit-dots are abundant and midway between the midrib and margin, and the rachis shaggy with reddish-brown chaff and scales. 2 to 5 feet high.

Nutka, through Oregon and California to Guadalupe Island. 
82. Variety nudatum, Eaton. (The bare variety.)

Rachis and usually the stalk devoid of chaff and scales; pinnæ few, short, oblong-oval; fruit-dots few, at the ends of the uppermost pinnæ.

Yosemite (Wood), and Moore's Flat, California. A rare form.

83. Variety imbricans, Eaton. (The overlapping variety.)

Pinnæ overlapping each other, oblong-lanceolate; fruit-dots nearer the margin; stalk with brown, shining scales, otherwise naked.

California; Red Mt. (Kellogg), Trinity River (Wood), and Sierras (Mrs. Austin).

84. Variety inciso-serratum, Eaton. (The cut-serrate variety.)

Frond large; pinnæ lanceolate, acuminate, deeply cut and serrate; fruit-dots scattered.

Only from British Columbia, so far.

85. A. juglandifolium, Kunze. (The walnut-leaved A.)

Pinnæ 3 to 13 , ovate-oblong or lanceolate, terminal ones the largest, all finely serrate, smooth; fruit-dots scattered in several irregular rows between the midrib and margin. Lower pinnæ stalked. 6 to 24 inches high.

Western Texas. Common farther south to Tropical America.

++ Fronds almost or fully bi-pinnate.

86. A. aculeatum, Swartz. (The bristly A.)

Pinnæ crowded, lanceolate from a broad base, curved, parted or divided ; final divisions entire, serrate, or cut ; under surface chaffy ; fruitdots nearer the midrib: stalks and rachis very chaffy. I to 3 feet high. In the typical form, fronds lanceolate and pinnæ enlarged at base on the upper side.

California; Santa Cruz (Bolander), Ukiah (Kellogg). Europe.

87. Variety Californicum, Eaton. (The Californian variety.)

Fronds thin, narrowed at base, elongated; pinnæ cleft at the base and but slightly cut above; upper side of the base of the pinnæ not greatly enlarged. (A. Californicum, Eaton.)

California; Santa Cruz (Bolander), Ukiah (Kellogg).

88. Variety lobatum, Kunze. (The lobed variety.)

Fronds lanceolate; pinnæ lanceolate, base broad, divided into distinct and sessile pinnules, some of the lowest enlarged at base on the upper side. (Varieties lobatum and intermedium, Hooker.)

Santa Cruz and Mendocino County, California. Europe.

89. Variety ฉngmlare, Braun. (The angled variety.)

Fronds oblong-lanceolate, fully bi-pinnate; pinnules stalked, somewhat cut, lowest ones largest and parted. ( $A$. angulare, Willdenow.)

Santa Cruz, California. In damp ravines. rocks.)

90. Variety scopulinmm, Eaton. (The variety growing among

Fronds narrowly lanceolate, short, short-stalked, almost leathery, pinnate; pinnæ ovate, an inch long, lower half lobed, upper half serrate only; fruit-dots near the midrib. May be a form of No. 93. Resembles No. 80 .

Santa Cruz and Mendocino County, California, to Salt Lake City (Jones).

9I. Variety Brommii, Koch. (Braun's variety.) 
Fronds tapering at base, bi-pinnate; otherwise as No. 89.

Rocky Mountains and eastward. Europe.

92. Variety proliform, Wollaston. (The proliferous variety.)

Fronds lanceolate, lax bi- or tri-pinnate, final divisions extremely delicate, tapering, distinctly stalked, usually with deep and widely spreading lobes, proliferous on the rachis.

San Rafael, California. Very rare.

+ Fronds not bristly toothed.

93. A. mohroioides, Bory.

Fronds oblong-lanceolate, almost leathery, narrowed below, pinnate; pinnæ many, $\mathrm{I} / 2$ to $\mathrm{I} / 2$ inches long, ovate or ovate-lanceolate, usually overlapping, obtuse, lobed, lobes scalloped; fruit-dots very large. Stalks chaffy. Rootstock short. About a foot high.

Mt. Eddy, California (Lemmon); Falkland Islands, Patagonia, Chili, Prince Edward's Islands. Very rare.

\section{CYSTOPIITIIS, Bernhardi. Bladder-FERn。}

Fruit-dots borne on the back of a straight branch of the free veins; indusium somewhat jagged on the edge, soon vanishing. Tufted ferns. (Greek for bladder-fern, from the bladdery indusium.)

A genus of 5 species, 3 in the United States. Growing in moist and shady places.

94. C. fragili:s, Bernhardi. (The frail C.)

Fronds once- to thrice-pinnate, oblong-lanceolate; pinnæ ovate or lanceolate, acute in the typical form; secondary rachis winged; final divisions irregularly cut.

Throughout the world.

95. Variety Mentata, Hooker. (The toothed variety.)

- Scarcely bi-pinnate; pinnules ovate, obtuse, bluntly toothed.

Abundant in California; less common eastward. Various parts of the world.

96. Variety laciniata, Davenport. (The cut variety.)

Fronds pinnate, narrowly lanceolate; pinnæ short, broadly lanceolate, parted, divisions deeply and irregularly cut into linear or acutely toothed lobes.

California and Colorado. varieties.

In the still unsettled knowledge of these forms, it is best to indicate what may prove to be good

97. C. montana, Bernhardi. (The mountain C.)

Fronds deltoid-ovate, tri-pinnate, final divisions almost again divided.

Mountains of Colorado and northward. Rare in our region.

\section{WOOSLA, R. BRown. Woodsia.}

Veins only forked. Our plants with pinnate, lanceolate fronds; pınnæ parted into scalloped or toothed divisions; fruit-dots near the margin. Rootstock short and creeping. Tufted ferns growing among rocks. About a foot high. (Dedicated to Joseph Woods, an English botanist.)

A genus of nearly $\mathbf{1} 5$ species, 7 in the United States. 
98. W. scopulina, Eaton. (The W. growing among rocks.)

Stalks quite dark, at least at base. Frond, rachis and stalks pubescent wtth stalked glands and flattened hairs; indusium delicate, deeply cut into several divisions which end in short hairs.

Mono Pass, California, and Oregon; east to Colorado.

99. W. Oregalla, Eaton. (The W. from Oregon.)

Stalk straw-colored. Fronds usually smooth; indusium minute, divided almost to the base into delicate beaded hairs: edge of frond sometimes incurved. Fertile fronds taller than the sterile.

Oregon to Lake Superior, Arizona and Colorado.

ıо. W. Mexicana, Fee. (The Mexican W.)

Fronds smooth: teeth of the divisions half-transparent at the tip and hairy on the edge in young fronds; indusium divided into 3 to 5 narrow parts, which are cut on the edges and divided half-way down into jointed hairs.

New Mexico and southward.

\section{SUB ORDETR II.-SCHIZRACERE.}

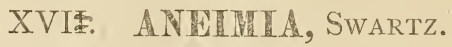

Fruit-dots ovate, sessile, completely surrounded by an indusium, which opens lengthwise by a slit, and has a complete ring at the top; placed in two rows one on each side of the midrib of the very narrow divisions of the two lower, long-stalked branches of a panicled, pinnately divided frond.

A genus of about 27 species; mostly South American.

ıог. A. Mexieana, Klotzsch. (The Mexican A.)

Fronds scattered; pinnate, on slender stalks: the two lower branches fertile, long-stalked, glandular-pubescent, bi-pinnate, densely fruited: the rest of the frond sterile, deltoid-ovate, simply pinnate; pinnæ about six pairs and a larger terminal one, short-stalked, broadly ovate-lanceolate, almost leathery, smooth: veins parallel, close together; the veinlets running into the fine teeth on the edge of the frond. Rootstock creeping, covered with narrow, awl-shaped, blackish chaff. I2 to I 8 inches high.

Western Texas and New Mexico. 


\section{GLOSSARY.}

Acuminate, tapering to a point.

Acute, sharp pointed.

Alternate, (see page 4.)

Azul-shaped, tapering to a fine point from a broad base.

Beaded, with the edges curved in so as to make the part seem like a bead or ball.

$B i$-; twice; bi-pinnate, twice pinnate.

Cleft, gashed deeply.

Concave, curving inwards.

Cut, (see page 3.)

Deltoid, three-cornered, with the sides of equal length.

Distant, separated from each-other.

Divided, (see page 3.)

Elliptical, oblong, with the ends gradually rounded.

Entire, with a smooth, unbroken margin.

Epidermis, the outer skin of the frond.

Erect, standing straight, not bent over nor creeping.

Fertile, fruit-bearing.

Free, not united with other veins or veinlets.

Genus, a group of different but related species.

Glandular, having protuberances or depressions which secrete a sticky fluid.

Glaucous, covered with a white powder, which rubs off easily.

Granular, covered with small grains or loose, rough bodies.

Halbert-shaped, shaped like the head of a spear, with two prongs at the base pointing outwards.

Indusium, (see page 4.)

Involucre, (see page 4.)

Lacerate, deeply and irregularly cut along the edge.

Lanceolate, shaped like an egg, but with the small end tapering to a point.

Linear, three or more times longer than wide and with parallel sides. Ex., a grass leaf.

Lobe, (see page 3.)

Midrib, (see page 3.)

Oblong, not three times as long as wide, and with (nearly) parallel sidés.

Obovate, shaped like an egg with the little end down (when the leaf is held upright).

Obtuse, with a rounded or blunt point.

Opposite, (see page 4.)

Oval, shaped like an egg, but both ends of equal size.

Ovate, egg-shaped, with the large end down.
Panicle, an irregularly branched flowercluster.

Parted, (see pagə 3.)

Petiole, the stem of a leaf.

Pinna, plural pinne, (see page 3.)

Pinmule, (see page 3.)

Proliferous, with branches arising from branches.

Prothallium, (see page 2.)

Pubescent, with short or long hairs.

Quadri-, four times.

Rachis, (see page 3.)

Recurved, curved over upon itself.

Resinous, with waxy dots.

Rootstock, what passes for the root in ferns is really an under-ground stem, and is called by this name.

Scales, thin and papery or leathery bodies, like chaff, that clothe the rootstock and often the fronds of ferns.

Serrate, (see page 3.)

Sessile, without a stalk, and so attached directly to the place of support.

Smooth, with an even surface, without roughness.

Species, the name applied to each kind of ferns or any plants that have the same characteristics.

Spike, with the fruit or flowers situated along a common stalk and devoid of a stalk of their own.

Spore (see page 2); Spore-case, (see page 3.)

Stellate, star-shaped.

Sterile, barren, without fruit.

Stipe, (see page 3.)

Strice, fine parallel lines.

Tazeny, dirty white or brown.

Ternate, divided in threes.

Toothed, (see page 3.)

Triangular, three-cornered.

Tri-, three times, thrice.

Truncate, ending abruptly, as if cut square across.

Tufted, growing in bunches.

Typical, the form of a species upon which the original description was based, and distinct from the descriptions of varieties afterwards discovered.

Veins, (see page 3.)

Veinlets, (see page 3 ), little veins.

Viscid, sticky, like molasses.

Wing; a thin or papery appendage, attached

like the feather to an arrow.

Woolly, with long, twisted, matted hairs. 



\section{INDEX. \\ PAGE.}

Adiantum ........... IO, 2 I

Capillus-Veneris, L........ 4, 2 I emarginatum, Hooker ........ 2 I pedatum, L ............... 2 I tricholepis, Fee ........... 2 I

Aneimia ....... 6, 7, I I, 28 Mexicana, Klotzsch . - . 28

Aspidieæ ........... 7, I I , 23

Aspidium . . . . . . . II, 24-27 aculeatum, Swartz ............... 26

var. angulare, Braun ....... . 26

var. Braunii, Koch. . . . . . . . 26

var. Californicum, Eaton . . . . . 26

var. lobatum, Kunze ...... 26

var. proliferum, Wollaston ...... 27

var. scopulinum, Eaton ..... 26

Filix-mas, Swartz......... 25

fragrans, Swartz.................... 25

juglandifolium, Kunze............ 26

Lonchitis, Swartz ........ 25

mohrioides, Bory . . . . . . . . . 27

munitum, Kaulf. ............ . . 25

var. imbricans, Eaton ........26

var. inciso-serratnm, Eaton ..... 26

var. nudatum, Eaton ... . . . 26

Nevadense, Eaton. ....... 24

Oreopteris, Sav. . . . . . . . . . . 25

patens, Swartz . . .

rigidum, Swartz var. argutum, Eaton. . . . 25

spinulosum, Swartz var. dilatatum, Eaton. . 25

Asplenieæ.

Asplenium ..... II, 22-23

Filix-fœmina, Bernh. . . . . . 23

var. angustum, Eaton ........... 23

var. commune, Eaton ....... 23

var. cyclosorum, Rup. ....... 23

var. latifolium, Hooker ..... . . . 22

parvulum, Mart. \& Gal . ........ 22

septentrionale, Hoffmann . . . . . . 23

Trichomanes, L.

var. incisum, Moore ........ 22

viride, Hudson . . . . . . . . . . 23

Beech-Fern ............... . . . . 3

Bladder-Fern. . . . . . 3, 4,27

Blechnea........... . 7, I0, 2 I

Botrychium . . . . . . . . . . .

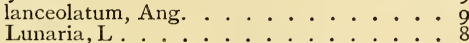

simplex, Hitch. var. compositum, iMilde . 8

ternatum, Swartz . . . . . . . . . 9

Virginianum, Swartz .

Bracken

Brake....... 4, 20

Chain-Fern .. . . . . . . . . 3, 22

Cheilanthes ............... 10, 15

Alabamensis, Kunze. . . . . . . I5

argentea, Kunze. . . . . . . . . . . I7

Californica, Mett . . . . . . . . . . 15

Clevelandii, Eaton .......... . . 17

Cooperæ, Eaton. . . . . . . . . . I6

Eatoni, Baker . . .

Fendleri, Hooker. . . . . . . . . . . I7

gracillima, Eaton ........... . . . I7

lanuginosa, Nuttall ......... is, r6

leucopoda, Link. . . . . . . . I6

Lindheimeri, Hooker . . . . . . . 7, r 7

microphylla, Swartz........ . . . $\mathbf{r}_{5}$

myriophylla, Desv . . . . . . . . 7, 17

Parishii, Dav. ............ I7

tomentosa, Link. . . . . . . . . . . I6

viscida, Dav ............. I5

viscosa, Kaulf. . . . . . . . . . . . . I6

Wrightii, Hooker ........... . I5

Cliff-Brake. .... 2, 3, 4, r8

Climbing-Fern ... . . . . . . . . . . 3

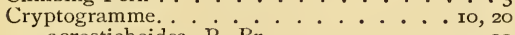
acrostichoides, R. Br ......... 20

Cystopteris ............ II, 27

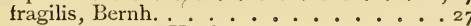

var. dentata, Hooker ....... 27

var. laciniata, Dav ................ 27

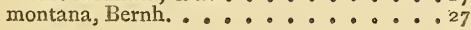

Female-Fern PAGE.

FILICES ...............

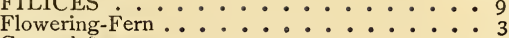

General,

Gold-Fern ................ 42

GRAMMITIDE ............ 7, 10, 12

Gymnogramme ............ 10, 12

hispida, Mett. .......... I2

triangularis, Kaulf. . . . . . . . . I2

var. viscosa, Eaton......... 12

Habits, $33 . . .0 . . . . .44$

How to Analyze, 36.

Hymenophyllum.............. 3

Lip-Fern.............. 3, I5

Lomaria. . . . . . .

Spicant, Desvaux ................ I

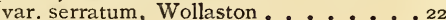

Maiden-Hair ............... 4 , I

Male-Fern . . . . . . . . 25

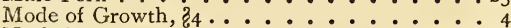

Notholæna. ....... 7, ro, 12-14, I5

candida, Hooker.......... IO, 13

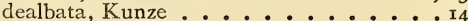

Fendleri, Kunze .......... . . I4

ferruginea, Hooker ......... I4

Grayi, Davenport ....... I3, Io, I4

Hookeri, Eaton ........... Io, I3

Lemmoni, Eaton ............... 14

Newberryi, Eaton .......... I3

nivea, Desvaux ............ I4

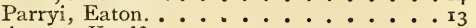

sinuata, Kaulf. . . . . . . . . I4

tenera, Gillies . . . . . . . . . . . . 14

Ophioglossaceæ ...................

Ophioglossum vulgatum, I.............

Ostrich-Fern ............. 3

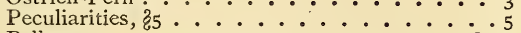

..... 10, $18-20$

andromedæfolia, Fee .............. 8

var. pubescens, Baker... . * . . . 18

aspera, Baker......... 18

atropurpurea, Link . . . . . . . . 18

brachyptera, Baker. . . . . . . . . I9

Breweri, Eaton . . . . 8

Bridgesii, Hooker . . . . . . . . . I9

densa, Hooker . . . . . . . . . . . I9

flexuosa, Link. . . . . . . 20

gracilis, Hooker . . . . . . . . . . . 18

Ornithopus, Hooker . . . . . . . . . . I9

pulchella, Fee............ I9

ternifolia, Link . . . . . . . . . . . r9

Wrightiana, Hooker.

Phegopteris .......... Io, I I , 23-24

alpestris, Mett. . . . . . . . 24

Dryopteris, Fee. . . . . . . . . . . 24

polypodioides, Fee ........ . 24

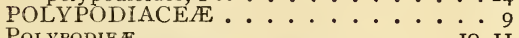

Polypodief $\cdots$ IO, I I

Polypodium Californicum, Kaulf. . . . . . I2

falcatum, Kellogg ............ . . I I

Scouleri, Hooker \& Arnot. . . . . . . . I2

vulgare, L. . . . . . . I I, I2

var. occidentale, Hooker. . . . . . . I I

Polypody ............. 3,6 , I I

PTERIDEAE. . . . . . . . . . . 7 , IO, I 5

Pteris. . * * * * * * aquilina, $\dot{L}$ var. lanuginosa, Bong... . . . 20

Rock-Brake............... 4, 20

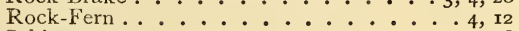

Schizacer..............

Sensitive-Fern ......... 3

Shield-Fern .................... 3

Spleenwort . . . . . . . . . . $3,4,22$

Walking-leaf-Fern. ........ 3

What Next? $87 . . .2 . . .27$

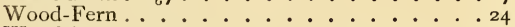

Woodsia............ Io, Ir, 27

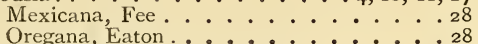

scopulina, Eaton .............. 27

Woodwardia. .............. 10, 22 radicans, Smith var. Americana, Hooker . 22 


$$
9402
$$







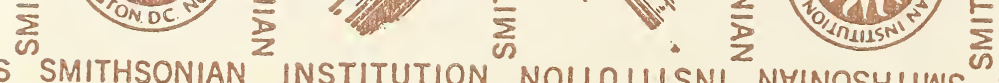

ES SMITHSONIAN _ INSTITUTION NOIINIIISNI NHINOSHIIWS S

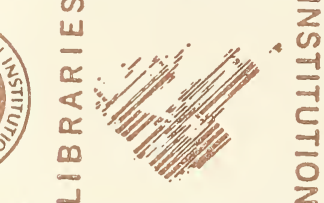

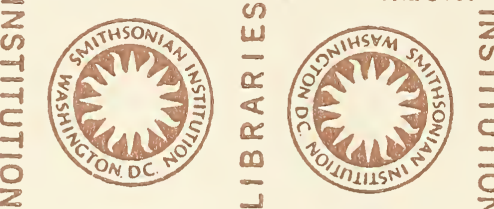

NHINOSHLIWS

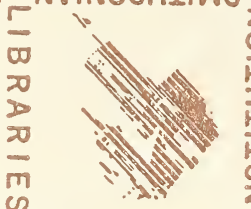

(n)

ES SMITHSONIAN

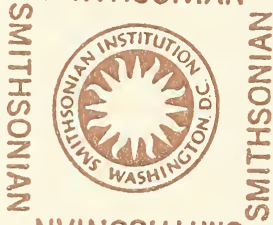

NI NHINOSHIIWS

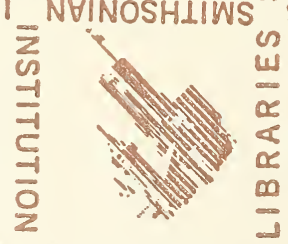

SMITHSONIAN
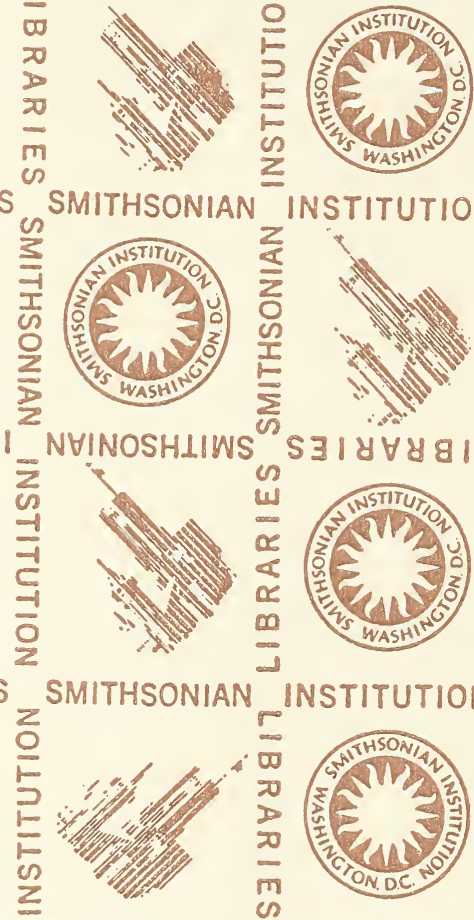

$\frac{5}{\infty}$

INSTITUTION

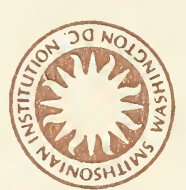

NOIIN1I1SNI
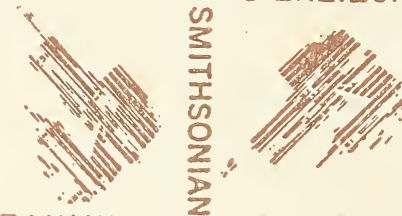

S3I8 Y $8917^{2} L I B R A R I E S$
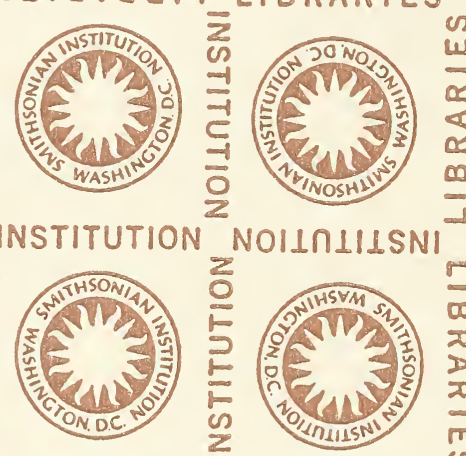

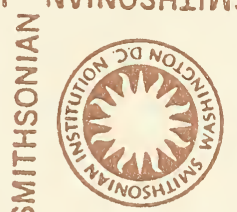

$\frac{1}{3}$

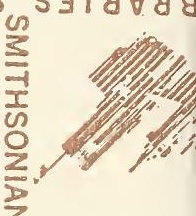

$\frac{\omega}{\infty}$
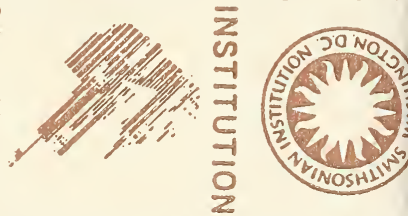

NHINOSHLIWS
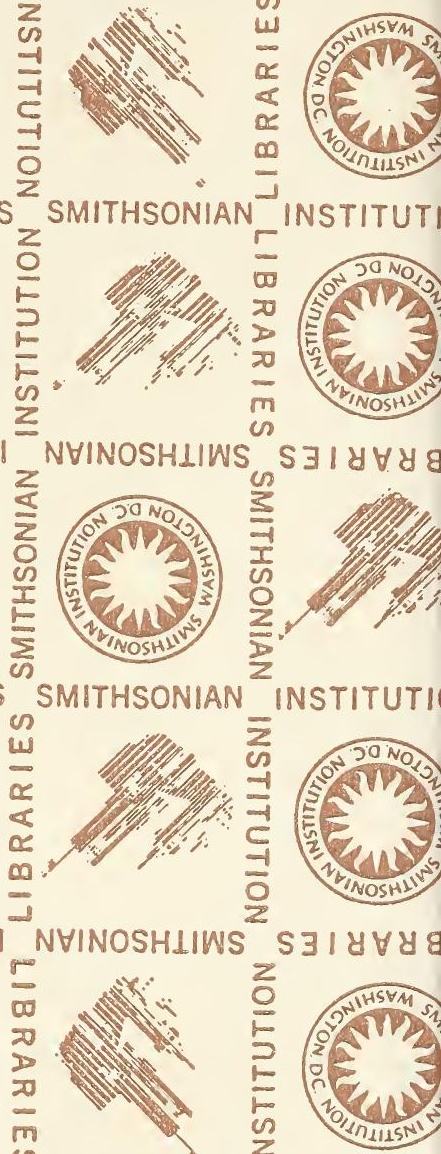
.

es

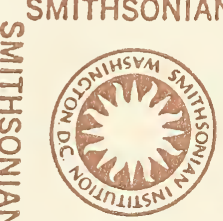

INSTITUTI
NHINOSHLIWS

$$
\begin{aligned}
& 2 \\
& \frac{2}{2} \\
& 0 \\
& \frac{1}{1} \\
& \frac{1}{n}
\end{aligned}
$$

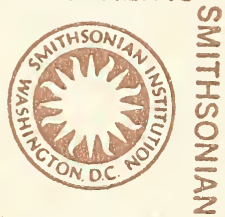

S $\exists 18 \forall 8817$
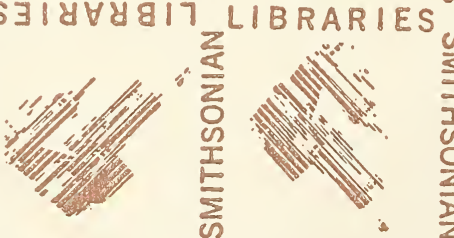

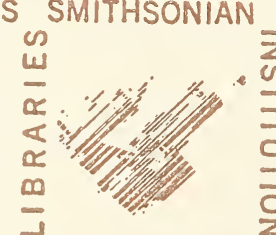

NI NVINOSHLIWS

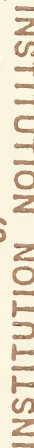

INSTITUTION
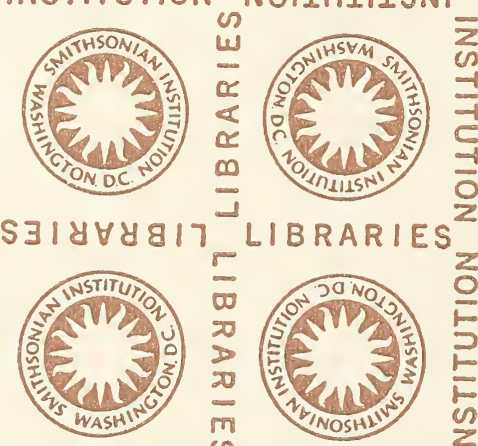

$\frac{2}{2}$
NHINOSHIINS

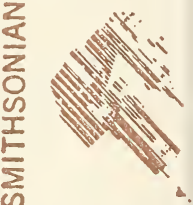

S $\exists I y \forall \forall 8$
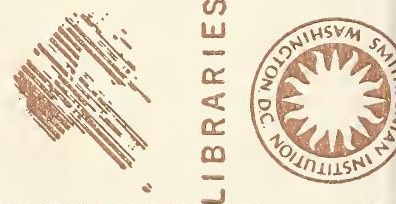
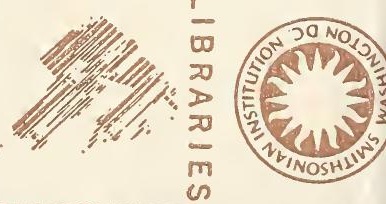

SMITHSONIAN INSTITUTION LIBRARIES

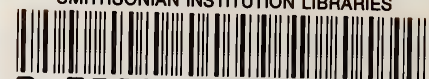

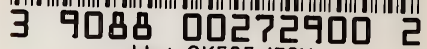
nhbot OK525.J78X Ferns of the West, 